\title{
PENGARUH MEREK DAN PERSONAL SELLING TERHADAP KEPUTUSAN PEMBELIAN PRODUK DVD PLAYER ELECOR PADA PT. CAKRAWALA ELECORINDO MEDAN
}

\author{
Ina Namora Putri Siregar 1)*, Elisabeth Natalia ${ }^{2)}$ \\ 1) Fakultas Ekonomi, Universitas Prima Indonesia \\ Email: inanamoraputri@gmail.com \\ 2) Fakultas Ekonomi, Universitas Prima Indonesia \\ Email: eli_natalia@yahoo.com
}

\begin{abstract}
Abstrak
PT.Cakrawala Elecorindo merupakan salah satu perusahaan yang menjual produk Elecor di kota Medan. Permasalahan yang terjadi adalah keputusan pembelian yang semakin menurun, merek yang kurang dikenal oleh masyarakat, dan personal selling tidak memahami produk yang akan dijual. Berdasarkan uraian singkat tersebut, maka dirumuskan masalah sebagai berikut bagaimana pengaruh merek dan personal selling terhadap keputusan pembelian produk dvd player Elecor pada PT.Cakrawala Elecorindo. Teori yang digunakan dalam penelitian ini adalah teori Manajemen Pemasaran, yang berkaitan dengan Merek, Personal Selling dan Keputusan Pembelian. Metode penelitian menggunakan pendekatan kuantitatif, jenis penelitian adalah penelitian deskriptif, sifat penelitian adalah deskriptif explanatory. Metode pengumpulan data dilakukan dengan wawancara, kuesioner, dan observasi. Metode analisis yang digunakan adalah analisis regresi linier berganda. Populasi adalah seluruh pelanggan PT.Cakrawala Elecorindo yang berjumlah 100 toko. Penentuan jumlah sampel menggunakan sampel jenuh dimana 30 toko untuk uji validitas dan uji reliabilitas. 70 toko untuk uji responden. Hasil penelitian menunjukkan bahwa merek dan personal selling secara simultan dan parsial berpengaruh signifikan terhadap keputusan pembelian DVD player Elecor pada PT.Cakrawala Elecorindo. Merek dan personal selling memberikan informasi yang dibutuhkan sebesar 38,4\% dalam keputusan pembelian produk DVD player Elecor pada PT. Cakrawala Elecorindo dan sisanya sebesar $61,6 \%$ dijelaskan oleh kualitas produk, harga, dan lain sebagainya.
\end{abstract}

Keywords : Merek, Personal Selling, Keputusan Pembelian 


\section{PENDAHULUAN}

Pada era globalisasi ini, perkembangan teknologi berkembang semakin pesat. Hal ini dapat dilihat dari semakin canggih teknologiteknologi yang diciptakan oleh perusahaan dengan tujuan untuk memenuhi kebutuhan konsumen. Teknologi dapat berupa alat-alat elektronik yang biasa digunakan untuk memenuhi kebutuhan para konsumen Dengan semakin banyak orang yang menggunakan alatalat elektronik maka semakin banyak pula perusahaan yang memproduksi alat-alat elektronik yang canggih sehingga terjadi persaingan antar perusahaan.

Hal yang harus dilakukan perusahaan untuk memenangkan pelanggan dari pesaing yaitu memahami kebutuhan dan keinginan para konsumen. Dengan memahami kebutuhan dan keinginan konsumen maka dapat tercipta keputusan pembelian konsumen pada suatu perusahaan. Dalam memasarkan produknya, perusahaan membutuhkan tenaga penjual (personal selling) yang handal sehingga produk pada perusahaan dapat dikenal oleh konsumen serta merek produk pada perusahaan tersebut juga dapat dikenal oleh konsumen. Merek yang dikenal oleh konsumen serta tenaga penjual yang memiliki kemampuan dalam memasarkan produknya akan mempengaruhi proses pengambilan keputusan pembelian konsumen pada perusahaan tersebut.

PT. Cakrawala Elecorindo merupakan perusahaan yang bergerak di bidang alat-alat elektronik. PT. Cakrawala Elecorindo merupakan salah satu perusahaan yang menjual produk Elecor di kota Medan dan juga merupakan distributor alat-alat elektronik di kota Medan. PT. Cakrawala Elecorindo memiliki kantor yang beralamat di Jalan William Iskandar Komp. MMTC Blok. C No.8 Medan. Barang yang dijual oleh PT. Cakrawala Elecorindo seperti : DVD player, Rice Cooker, Antena Digital, Receiver, dan lain-lain.

Keputusan pembelian yang diambil oleh konsumen atau pelanggan dalam memilih atau membeli sebuah produk yang ditawarkan didasari oleh produk yang memiliki merek yang terkenal sehingga konsumen tidak akan ragu dalam membeli produk tersebut serta bagaimana cara personal selling mempresentasikan produk yang akan dijual dan bagaimana personal selling meyakinkan konsumen atau pelanggan agar melakukan keputusan pembelian. Keputusan pembelian merupakan suatu tindakan atau
NIAGAWAN Vol 7 No 2 Juli 2018 perilaku konsumen jadi atau tidaknya melakukan suatu pembelian atau transaksi, serta banyak tidaknya jumlah konsumen dalam mengambil keputusan menjadi salah satu penentu tercapai atau tidaknya tujuan perusahaan untuk mendapatkan keuntungan. Permasalahan yang dihadapi PT. Cakrawala Elecorindo yaitu penurunan penjualan DVD player Elecor serta target yang ditetapkan perusahaan tidak tercapai. Merek merupakan faktor pendukung konsumen dalam memilih suatu produk sehingga merek yang mudah diingat akan mempengaruhi proses pengambilan keputusan pembelian. Merek merupakan identitas/nama dari suatu produk dimana pelanggan dapat dengan mudah mengenali produk yang dijual oleh suatu perusahaan. Dengan adanya merek, maka pelanggan lebih mudah mengenali barang atau jasa yang dijual oleh suatu perusahaan. Permasalahan yang dihadapi oleh PT. Cakrawala Elecorindo yaitu menurunnya tingkat penjualan produk DVD player Elecor pada PT. Cakrawala Elecorindo Medan dikarenakan menurunnya ketertarikan konsumen terhadap produk, serta merek yang kurang dikenal oleh kalangan masyarakat sehingga konsumen menggunakan produk dari perusahaan lain yang sudah dikenal dikalangan masyarakat.

Faktor lain yang mempengaruhi penurunan keputusan pembelian adalah Personal Selling (penjualan personal) atau yang biasa disebut wiraniaga. Salah satu bentuk promosi penjualan yang dapat dilakukan oleh perusahaan selain produknya dapat dikenal langsung oleh masyarakat/calon pembeli juga dapat menggugah hati pembeli untuk melakukan pembelian langsung pada saat itu juga, cara ini adalah penjualan tatap muka atau sering disebut personal selling. Diharapkan dari kegiatan personal selling ini dapat menciptakan hubungan yang harmonis dengan konsumen karena proses penjualan yang dilakukan dengan mengunjungi calon pembeli dan interaksi langsung. Permasalahan yang dihadapi oleh PT. Cakrawala Elecorindo yaitu komplain pelanggan terhadap personal selling PT. Cakrawala Elecorindo semakin bertambah. Jenis komplain pelanggan terhadap personal selling pada PT.Cakrawala Elecorindo seperti tidak memahami dengan benar produk yang akan dijual, sulit dihubungi, kurang ramah terhadap pelanggan, tidak datang tepat waktu ke tempat pelanggan, kurang komunikasi baik dengan pelanggan. 


\section{TINJAUAN PUSTAKA}

\section{II.1 Teori Tentang Merek \\ II.1.1 Pengertian Merek}

Menurut Kotler dan Armstrong (2008:275), "Merek adalah: Nama, istilah, tanda, lambang, atau desain, atau kombinasi dari semua ini yang memperlihatkan identitas produk atau jasa dari satu penjual atau sekelompok penjual dan membedakan produk itu dari produk pesaing."

Menurut Hasan (2014:202), "Merek dimaknai sebagai kombinasi dari "sebuah nama, tanda, simbol atau desain untuk mengidentifikasi barang dan jasa dari satu usaha atau kelompok usaha yang dikembangkan menjadi merek dagang dan membedakan diri dari pesaing, menciptakan pengaruh dan menghasilkan nilai bagi perusahaan."

Menurut Sunyoto (2014:101), "Merek adalah tanda yang berupa gambar, nama, kata, huruf-huruf, angka-angka, susunan warna, atau kombinasi dari unsur-unsur tersebut yang memiliki daya pembeda dan digunakan dalam kegiatan perdagangan barang atau jasa."

Dalam pembahasan diatas dapat disimpulkan bahwa merek merupakan nama, tanda, simbol, rancangan, desain atau kombinasi untuk mengidentifikasikan suatu barang atau jasa yang dijual oleh perusahaan ke konsumen. Dengan adanya merek, maka konsumen akan terbantu dan dapat membedakan suatu merek dengan merek yang lain.

\section{II.1.2 Arti Penting Merek}

Menurut Rachman (2010:150), menyatakan bahwa "Merek yang ampuh mempunyai nilai merek yang tinggi. Merek mempunyai nilai merek lebih tinggi kalau mempunyai loyalitas merek, kesadaran merek, anggapan mutu, asosiasi merek lebih tinggi, dan asset lain seperti paten, merek dagang, dan hubungan saluran. Sebuah merek dengan nilai merek yang kuat merupakan aset yang amat berharga. Sebenarnya, merek dapat dibeli atau dijual dengan harga tertentu."

Menurut Hasan (2014:203), "Pelaggan bersedia membayar dengan harga premium yang substansial bagi sebuah merek yang baik dan tetap loyal terhadap merek tersebut, hubungan merek dengan pelanggan telah mampu menciptakan keuntungan, merek-merek yang mampu menciptakan hubungan kenyamanan dan keamanan dengan konsumen."

Menurut Kotler dan Gary Armstrong (2008:275), "Merek sebagai bagian penting dari produk, dan penetapan merek bisa menambah nilai bagi suatu produk. Penetapan merek menjadi begitu kuat sehingga saat ini tidak ada produk yang tidak memiliki merek"

Dalam pembahasan diatas dapat disimpulkan bahwa, merek merupakan suatu nama atau simbol yang mengidentifikasi suatu produk dan membedakannya dengan produk- produk yang lain. Merek mampu menciptakan hubungan kenyamanan dan keadaman dengan konsumen.

\section{II.1.3 Faktor-faktor yang Mempengaruhi Merek}

Menurut Hasan (2014:207-210), ada 9

faktor yang mempengaruhi merek, yaitu sebagai berikut:

1. No brand identify

Tidak ada identitas merek dan hanya nama perusahaan yang mungkin disebabkan oleh kurangnya dukungan finansial, memberikan produk dengan harga lebih rendah.

2. Specific branding

Jika perusahaan beroperasi di pasar asing dengan produk yang diberi merek tertentu atau sering disebut a specific product brand.

3. Private brand

Menggunakan merek milik perantara dalam menjual produk ke pasar asing.

4. Manufacturer's brand-corporate branding Menggunakan merek perusahaan sendiri dalam menjual produk di pasar seperti IBM dan memakai merek yang sama baik di luar negeri maupun di dalam negeri.

5. Multiple brand

Menggunakan beberapa merek dalam satu pasar (combination a product line branding).

6. Single brand

Perusahaan hanya menggunakan satu merek di dalam satu pasar.

7. Local brand

Menggunakan merek yang khusus bagi setiap pasar baik lokal, nasional, maupun pasar asing.

8. Worldwide brand

Menggunakan satu merek untuk menjual produk ke seluruh dunia.

9. Brand community

Brand community atau komunitas merek ,merupakan serangkaian struktural dari hubungan sosial para pengguna merek.

\section{II.1.4 Manfaat dan Tujuan Merek}

Menurut Sunyoto (2014:103-108), pemberian nama merek atas suatu produk menjadi sangat penting dan mempunyai manfaat, antara lain:

1. Bagi Konsumen

Manfaat nama merek suatu produk bagi konsumen di antaranya:

a. Mempermudah konsumen meneliti produk atau jasa.

b. Membantu konsumen atau pembeli dalam memperoleh kualitas barang yang sama, jika mereka membeli ulang serta dalam harga.

2. Bagi Penjual

Manfaat nama merek suatu produk bagi penjual di antaranya:

a. Nama merek memudahkan penjualan untuk mengolah pesanan-pesanan dan menekan permasalahan. 
b. Merek juga akan membantu penjual mengawasi pasar mereka karena pembeli tidak akan menjadi bingung.

c. Merek memberi penjual peluang kesetujuan konsumen pada produk.

d. Merek juga dapat membantu penjual dalam mengelompokkan pasar ke dalam segmen-segmen.

e. Citra perusahaan dapat dibina dengan adanya merek yang baik.

f. Dengan merek akan melindungi penjualan dari pemalsuan ciri-ciri produk tersebut.

Menurut Hasan (2014:203-204) menyatakan tujuan penggunaan merek sebagai berikut:

1. Sebagai identitas, yang bermafaat sebagai pengendali pasar dalam diferensiasi produk dengan produk pesaing yang memudahkan konsumen untuk mengenalinya saat melakukan pembelian ulang.

2. Alat promosi, yaitu sebagai daya tarik produk.

3. Untuk membina citra, yang memberikan keyakinan jaminan kualitas, serta prestise tertentu kepada konsumen.

4. Untuk mengendalikan pasar.

5. Menciptakan keuntungan kompetitif, jika merek yang memiliki ekuitas yang tinggi akan menghasilkan keuntungan sebagai berikut:

a. Dapat memberikan pertahanan terhadap persaingan harga yang kompetitif.

b. Perusahaan akan lebih mudah meluncurkan perluasan merek karena produk memiliki kredibilitas yang tinggi.

c. Mampu bertahan pada harga yang lebih tinggi dari pesaing karena konsumen memliki keyakinan terhadap kualitas produk.

d. Pelanggan sangat mengharapkan merek yang mereka maksud sehingga posisi tawar menawar produsen dengan distributor-pengecer lebih kuat.

e. Karena tingkat kesadaran dan kesetian konsumen terhadap merek sangat tinggi maka perusahaan dapat menikmati biaya pemasaran yang lebih rendah.

\section{II.1.5 Indikator Merek}

Menurut Sunyoto (2014:110), indikator merek yaitu :

1. Mudah dibaca, diucapkan, dan diingat.

2. Singkat dan sederhana.

3. Mempunyai ciri khas tersendiri dan disenangi oleh konsumen.

4. Merek harus menggambarkan kualitas produk.

5. Merek harus dapat didaftarkan dan mempunyai perlindungan hukum.
NIAGAWAN Vol 7 No 2 Juli 2018

\section{II.2 Teori Tentang Personal Selling \\ II.2.1 Pengertian Personal Selling}

Menurut Laksana (2008:151),

"Penjualan tatap muka (Personal Selling) adalah presentasi lisan dalam suatu percakapan dengan satu atau lebih calon pembeli untuk tujuan penciptakan penjualan."

Menurut Hermawan (2012:106),

"Penjualan personal (personal selling) merupakan pemasaran produk atau jasa di mana penjual bertemu langsung dengan pembeli untuk menjajaki prospek (peluang) pembelian."

$$
\text { Menurut Rangkuti (2009:26), }
$$

"Penjualan perseorangan ini merupakan alat promosi yang berbeda dari periklanan karena penjualan perseorangan menggunakan orang atau individu dalam pelaksanaannya."

Dalam pembahasan diatas dapat disimpulkan bahwa, personal selling adalah pemasaran produk atau jasa di mana penjual bertemu langsung dengan pembeli biasanya menggunakan orang atau individu dalam pelaksanaannya.

\section{II.2.2 Arti Penting Personal Selling}

Menurut Swastha (2012:30-31), "Penjualan tatap muka dilakukan dengan komunikasi dua arah antara penjual dan pembeli yang memungkinkan pesan-pesan penjualan disesuaikan dengan lingkungan dan kondisi konsumen. Penjualan tatap muka sangat penting pada saat diperlukan demonstrasi atau penjelasan yang mendalam tentang produknya."

Menurut Hasan (2014:604), "Penjualan personal (personal selling) merupakan bentuk presentasi secara lisan dengan satu atau lebih calon pelanggan dengan tujuan melakukan penjualan."

Menurut Hermawan (2012:109), "Spesifikasi penjual yang diinginkan perusahaan mungkin sulit dicari. Meskipun demikian, penjualan personal tetaplah penting dan biasanya dipakai untuk mendukung metode promosi lainnya."

Dalam pembahasan diatas dapat disimpulkan bahwa, personal selling mempunyai peranan penting dalam pemasaran produk dengan bentuk presentasi secara lisan dengan satu atau lebih calon pelanggan dengan tujuan melakukan penjualan serta bertujuan mendukung metode promosi lainnya.

\section{II.2.3 Faktor-faktor yang Mempengaruhi Personal Selling}

Menurut Sunyoto (2013:161), adapun faktor yang mempengaruhi bauran promosi bersifat produk ada tiga variabel penting, yaitu:

1. Nilai unit barang

Pada umumnya barang-barang bernilai rendah akan mempergunakan periklanan, sedangkan barang-barang yang bernilai tinggi, umumnya menggunakan personal selling.

2. Tingkat kebutuhan barang bagi konsumen 
Barang-barang yang sangat dibutuhkan penyesuaian langsung dengan kebutuhan konsumen, maka dipergunakan personal selling, akan tetapi jika produk dengan standar yang menguntungkan, maka lebih efektif menggunakan personal selling.

3. Presale and postsale service

Barang-barang yang memerlukan pelayanan sebelum dan sesudahnya melakukan penjualan, maka biasanya dipergunakan personal selling.

II.2.4 Manfaat dan Tujuan Personal Selling

Menurut Swastha (2012:31), beberapa manfaat lain dari penjualan tatap muka adalah :

1. Penjualan tatap muka secara khusus dapat diarahkan kepada calon konsumen tertentu.

2. Penjualan tatap muka lebih fleksibel karena jumlah angkatan penjualan dapat bebas ditentukan, mulai dari satu sampai ribuan.

3. Penjualan tatap muka ini dipandang lebih efektif dari periklanan dalam hal penciptaan penjualan dan realisasi penandatanganan formulir pesanan oleh konsumen.

Menurut Hermawan (2012:116), umumnya tujuan penjualan personal yang diterapkan secara intensif oleh suatu perusahaan adalah:

1. Meningkatkan penjualan produk.

Penjualan personal yang dilakukan perusahaan diharapkan dapat berdampak positif terhadap penjualan. Jika promosi lebih ditujukan untuk menarik perhatian konsumen dalam memenuhi keinginan atau kebutuhannya yang akan berdampak pada peningkatan penjualan secara tidak langsung, penjualan personal ditujukan untuk memberikan dampak langsung terhadap penjualan produk perusahaan.

2. Memperkenalkan produk kepada konsumen Dalam memperkenalkan produk kepada konsumen, perusahaan berusaha mencari celah untuk memenangkan pasar dan membangkitkan kesadaran akan merek, citra merek, dan citra perusahaan. Penjualan personal menjadi salah satu cara bagi perusahaan untuk memperkenalkan produk dengan

cara menawarkan dan menjelaskan fitur-fitur maupun keunggulan produk secara langsung kepada calon konsumen untuk mendorong mereka agar melakukan pembelian.

\section{II.2.5 Indikator Personal Selling}

Menurut Hermawan (2012:109), seorang tenaga penjualan atau wiraniaga harus memenuhi kriteria-kriteria sebagai berikut:

1. Salesmanship

Penjual harus memiliki pengetahuan tentang produk dan menguasai seni menjual, seperti cara mendekati pelanggan, memberikan presentasi dan demonstrasi, mengatasi penolakan pelanggan, dan mendorong pembelian.
2. Bernegosiasi

NIAGAWAN Vol 7 No 2 Juli 2018

Penjual harus mempunyai kemampuan untuk bernegosiasi tentang syarat-syarat penjualan.

3. Pemasaran hubungan (relationship marketing)

Penjual melakukan komunikasi hubungan antarmanusia yang efektif dengan mengetahui setiap karakter individu yang ditemuinya.

\section{II.3 Teori Tentang Keputusan Pembelian II.3.1 Pengertian Keputusan Pembelian}

Menurut Sangadji dan Sopiah (2013:121), "Keputusan pembelian adalah semua perilaku sengaja dilandaskan pada keinginan yang dihasilkan ketika konsumen secara sadar memilih salah satu diantara tindakan alternatif yang ada."

Menurut Kotler dan Armstrong (2008:181), "Keputusan pembelian konsumen adalah membeli merek yang paling disukai, tetapi dua faktor bisa berada antara niat pembelian dan keputusan pembelian."

Menurut Sunyoto (2013:89),

"Pengambilan keputusan merupakan proses kognitif yang mempersatukan memori, pemikiran, pemrosesan informasi dan penilaianpenilaian secara evaluatif."

Dalam pembahasan diatas dapat disimpulkan bahwa, keputusan pembelian adalah perilaku konsumen sengaja dilandaskan pada keinginan yang dihasilkan ketika konsumen secara sadar memilih salah satu diantara tindakan alternatif yang ada dengan melihat merek yang paling disukai.

\section{II.3.2 Arti Penting Keputusan Pembelian}

Menurut Feriyanto dan Triana (2015:138),"Pengambilan keputusan (decision making) adalah melakukan penilaian dan menjatuhkan pilihan. Keputusan ini diambil setelah melalui beberapa perhitungan dan pertimbangan alternatif."

Menurut Rangkuti (2009:122), "Proses pengambilan keputusan konsumen menunjukkan peta pikiran konsumen yang pemasar dan manajer bisa gunakan untuk membantu memberi arah bauran produk, komunikasi dan strategi penjualan."

Menurut Sangadji dan Sopiah (2013:123), "Pengambilan keputusan konsumen adalah proses pemecahan masalah yang diarahkan pada sasaran. Pemecahan masalah konsumen sebenarnya merupakan suatu aliran tindakan timbal balik yang berkesinambungan di antara faktor lingkungan, proses kognitif dan afektif, serta tindakan perilaku."

Dalam pembahasan diatas dapat disimpulkan bahwa, keputusan pembelian adalah proses pemecahan masalah yang diarahkan pada sasaran dengan mengkombinasikan pengetahuan untuk mengevaluasi dua atau lebih 
perilaku alternatif dan memilih salah satu di antaranya.

\section{II.3.3 Faktor-faktor yang Mempengaruhi Keputusan Pembelian}

Menurut Sangadji dan Sopiah (2013:2425), ada tiga faktor utama yang memengaruhi konsumen untuk mengambil keputusan, yaitu:

1. Faktor psikologis

Faktor psikologis mencakup persepsi, motivasi, pembelajaran, sikap, dan kepribadian. Sikap dan kepercayaan merupakan faktor psikologis yang memengaruhi keputusan pembelian konsumen.

2. Pengaruh faktor situasional

Faktor situasional mencakup keadaan sarana dan prasarana tempat belanja, waktu berbelanja, penggunaan produk, dan kondisi saat pembelian. Keadaan sarana dan prasarana tempat belanja mencakup tempat parkir, gedung, eksterior dan interior toko, pendingin udara, penerangan/pencahayaan, tempat ibadah, dan sebagainya.

3. Pengaruh faktor sosial

Faktor sosial mencakup undangundang/peraturan, keluarga, kelompok referensi, kelas sosial, dan budaya.

\section{II.3.4 Manfaat dan Tujuan Keputusan Pembelian}

Menurut Hasan (2014:184), "Manfaat keputusan pembelian adalah proses pengambilan keputusan pembelian berakhir pada tahap perilaku purnabeli di mana konsumen merasakan tingkat kepuasan atau ketidakpuasan yang dirasakan akan memengaruhi perilaku berikutnya. Jika konsumen merasa puas, ia akan memperlihatkan peluang yang besar untuk melakukan pembelian ulang atau membeli produk lain pada perusahaan yang sama di masa mendatang, dan cenderung merekomendasikan kepada orang lain. Banyak orang berpendapat bahwa pembeli yang tidak puas akan bereaksi dengan tindakan negatif seperti mendiamkan, melakukan komplain, bahkan merekomendasi negatif kepada orang lain tentang produk atau layanan buruk yang mereka alami."

Menurut Sangadji dan Sopiah (2013:2324), adapun yang menjadi tujuan dari pemahaman proses pengambilan keputusan konsumen adalah sebagai berikut:

1. Untuk memahami tipe-tipe proses pembuatan keputusan konsumen.

2. Untuk memahami langkah-langkah dalam setiap proses pengambilan keputusan konsumen.

3. Untuk mengetahui bagaimana konsumen belajar dan membeli produk.

\section{II.3.5 Indikator Keputusan Pembelian}

Menurut Sunyoto (2012:278-279), indikator keputusan pembelian yaitu:
1. Keputusan tentang jenis produk. Konsumen dapat mengambil keputusan untuk membeli sebuah produk. Dalam hal ini perusahaan harus memusatkan perhatiannya kepada orang-orang yang berminat membeli suatu produk serta alternatif lain yang mereka pertimbangkan.

2. Keputusan tentang bentuk produk. Keputusan ini menyangkut ukuran, mutu, corak dan sebagainya. Dalam hal ini perusahaan harus melakukan riset pemasaran untuk mengetahui kesukaan konsumen tentang produk bersangkutan agar dapat memaksimumkan daya tarik mereknya.

3. Keputusan tentang merek. Konsumen harus mengambil keputusan tentang merek mana yang akan dibeli. Setiap merek memliki perbedaan-perbedaan tersendiri. Dalam hal ini perusahaan harus mengetahui konsumen memilih sebuah merek.

4. Keputusan tentang penjualnya. Konsumen harus mengambil keputusan di mana produk tersebut akan dibeli. Dalam hal ini produsen, pedagang besar, dan pengecer baru mengetahui bagaimana konsumen memilih penjual tertentu.

5. Keputusan tentang jumlah produk. Konsumen dapat mengambil keputusan tentang seberapa banyak produk yang akan dibelinya pada suatu saat. Dalam hal ini perusahaan harus mempersiapkan banyaknya produk sesuai dengan keinginan yang berbeda-beda dari para pembeli.

Keputusan tentang cara pembayaran. Konsumen harus mengambil keputusan tentang metode atau cara pembayaran produk yang akan dibeli. Keputusan tersebut akan memengaruhi keputusan tentang penjual dan jumlah pembeliannya. Dalam hal ini perusahaan harus mengetahui keinginan pembeli terhadap cara pembayarannya.

\section{METODE PENELITIAN}

Metode penelitian menggunakan pendekatan kuantitatif, jenis penelitian adalah penelitian deskriptif, sifat penelitian adalah deskriptif explanatory. Metode pengumpulan data dilakukan dengan wawancara, kuesioner, dan observasi. Metode analisis yang digunakan adalah analisis regresi linier berganda. Populasi adalah seluruh pelanggan PT.Cakrawala Elecorindo yang berjumlah 100 toko. Penentuan jumlah sampel menggunakan sampel jenuh dimana 30 toko untuk uji validitas dan uji reliabilitas. 70 toko untuk uji responden, koefisien determinasi pengujian secara simultan (Uji-F) dan parsial (Uji-t). 


\section{HASIL DAN PEMBAHASAN}

Model penelitian dalam penelitian ini adalah model regresi linear berganda yang dimana model analisis ini digunakan untuk menguji hipotesis tentang pengaruh secara parsial variabel merek dan personal selling terhadap keputusan pembelian. Berdasarkan hasil persamaan regresi linear berganda maka dapat diperoleh hasil seperti pada tabel berikut: Tabel 1 Hasil Uji Regresi Linier Berganda

\begin{tabular}{|cc|c|c|}
\hline \multirow{2}{*}{\multicolumn{2}{|c|}{ Model }} & \multicolumn{2}{|c|}{$\begin{array}{c}\text { Unstandardized } \\
\text { Coefficients }\end{array}$} \\
\cline { 2 - 4 } & & B & Std. Error \\
\hline \multirow{2}{*}{1} & (Constant) & 3.987 & 4.691 \\
& Merek & .757 & .137 \\
& Personal Selling & .381 & .169 \\
\hline
\end{tabular}

a. Dependent Variable: Keputusan Pembelian Sumber: Hasil Penelitian, 2017 (Data diolah)

Berdasarkan tabel diatas, maka persamaan regresi linear berganda dalam penelitian ini sebagai berikut:

\section{Keputusan Pembelian $=3,987+0,757$ Merek} + 0,381 Personal Selling

1. Nilai konstanta regresi sebesar 3,987 artinya walaupun merek $\left(\mathrm{X}_{1}\right)$ dan personal selling $\left(X_{2}\right)=0$, maka keputusan pembelian tetap sebesar 3,987.

2. Koefisien regresi $X_{1}$ untuk variabel merek bernilai positif 0,757 artinya bahwa setiap terjadi peningkatan variabel merek sebesar 1 satuan, maka keputusan pembelian produk dvd player pada PT. Cakrawala Elecorindo akan meningkat sebesar 0,757 satuan.

3. Koefisien regresi $X_{2}$ untuk variabel personal selling bernilai positif 0,381 artinya bahwa setiap terjadi peningkatan dalam variabel personal selling sebesar 1, maka keputusan pembelian produk dvd player pada PT. Cakrawala Elecorindo akan meningkat sebesar 0,381 satuan.

Koefisien determinasi merupakan besaran yang menunjukkan besarnya variabel dependen (keputusan pembelian) yang dapat dijelaskan oleh variasi variabel independen (merek dan personal selling, hal ini dapat dilihat pada tabel berikut:

Tabel 2. Nilai Koefisien Determinasi $\left(\mathbf{R}^{2}\right)$

\begin{tabular}{|l|l|r|r|}
\hline Model & R & R Square & $\begin{array}{c}\text { Adjusted R } \\
\text { Square }\end{array}$ \\
\hline 1 & $.634^{\mathrm{a}}$ & .402 & .384 \\
\hline
\end{tabular}

a. Predictors: (Constant), Personal

Selling, Merek

b. Dependent Variable: Keputusan

Pembelian

Sumber: Hasil Penelitian, 2017 (Data diolah)
NIAGAW AN Vol 7 No 2 Juli 2018

Berdasarkan tabel diatas nilai Adjusted $R$ Square adalah 0,384 yang artinya 38,4\%, artinya bahwa kemampuan variabel keputusan pembelian (Y) dapat dijelaskan oleh variasi variabel merek $\left(\mathrm{X}_{1}\right)$ dan personal selling $\left(\mathrm{X}_{2}\right)$ adalah sebesar $38,4 \%$, sisanya sebesar $61,6 \%$ dijelaskan oleh variabel-variabel independen lainnya yang tidak diteliti dalam penelitian ini seperti kualitas produk, harga, promosi, dan lain sebagainya.

\section{Tabel 3. Hasil Pengujian Hipotesis Secara} Simultan / Uji F

\begin{tabular}{|l|c|c|}
\hline Model & F & Sig. \\
\hline Regression & 22.497 & $.000^{\mathrm{a}}$ \\
Residual & & \\
Total & & \\
\hline
\end{tabular}

a. Predictors: (Constant), Personal Selling, Merek

b. Dependent Variable: Keputusan Pembelian

Pada tabel di atas diperoleh hasil $F_{\text {hitung }}$ 22,497 dan $F_{\text {tabel }}$ pada tingkat signifikan 0,05 dengan derajat pembilang 2 dan derajat penyebut 67 diperoleh $F_{\text {tabel }} 3,13$ yang berarti $F_{\text {hitung }}>F_{\text {tabel }}$ dan nilai signifikan $0,000<0,05$. Hasil penelitian menunjukkan bahwa $\mathrm{H}_{1}$ diterima dan $\mathrm{H}_{0}$ ditolak. Hal ini menunjukkan bahwa merek dan personal selling secara bersama-sama berpengaruh positif dan signifikan terhadap keputusan pembelian produk dvd player Elecor pada PT. Cakrawala Elecorindo.

Tabel 4 Hasil Uji Hipotesis Secara Parsial

\begin{tabular}{|c|c|c|c|c|}
\hline \multirow[b]{2}{*}{ Model } & \multicolumn{2}{|c|}{$\begin{array}{l}\text { Unstandardized } \\
\text { Coefficients }\end{array}$} & \multirow[b]{2}{*}{$\mathrm{t}$} & \multirow[b]{2}{*}{ Sig. } \\
\hline & B & Std. Error & & \\
\hline 1 (Constant) & 3.987 & 4.691 & .850 & .398 \\
\hline Merek & .757 & .137 & 5.518 & .000 \\
\hline $\begin{array}{l}\text { Personal } \\
\text { Selling }\end{array}$ & .381 & .169 & 2.252 & .028 \\
\hline
\end{tabular}

a. Dependent Variable: Keputusan Pembelian Sumber: Hasil Penelitian, 2017 (Data diolah)

Pada tabel di atas diperoleh hasil sebagai berikut:

1. Nilai thitung untuk variabel merek sebesar 5,518 lebih besar dibandingkan dengan nilai $\mathrm{t}_{\text {tabel }} 1.996$ yang berarti $\mathrm{t}_{\text {hitung }}>\mathrm{t}_{\text {tabel }}$ dan pada tingkat signifikan $0,000<0,05$. Hasil penelitian menunjukkan bahwa $\mathrm{H}_{1}$ diterima dan $\mathrm{H}_{0}$ ditolak. Hal ini menunjukkan bahwa merek secara parsial berpengaruh positif dan signifikan terhadap keputusan pembelian 
produk dvd player Elecor pada PT. Cakrawala Elecorindo.

2. Nilai thitung untuk variabel personal selling sebesar 2,252 lebih besar dibandingkan dengan nilai $t_{\text {tabel }} 1.996$ yang berarti $t_{\text {hitung }}>$ $t_{\text {tabeldan }}$ pada tingkat signifikan $0,028<0,05$. Hasil penelitian menunjukkan bahwa $\mathrm{H}_{1}$ diterima dan $\mathrm{H}_{0}$ ditolak. Hal ini menunjukkan bahwa personal selling secara parsial berpengaruh positif dan signifikan terhadap keputusan pembelian produk dvd player Elecor pada PT. Cakrawala Elecorindo.

\section{Pengaruh Merek terhadap Keputusan Pembelian}

Hasil penelitian yang dilakukan peneliti membuktikan bahwa adanya pengaruh merek terhadap keputusan pembelian. Hal tersebut dibuktikan dengan hasil analisis uji t yaitu nilai $t_{\text {hitung }}>t_{\text {tabel }}(5,518>1.996)$ pada tingkat signifikan $(0,000<0,05)$. Hasil penelitian menunjukkan bahwa $\mathrm{H}_{1}$ diterima dan $\mathrm{H}_{0}$ ditolak. Hal ini menunjukkan bahwa merek secara parsial berpengaruh positif dan signifikan terhadap keputusan pembelian produk dvd player Elecor pada PT. Cakrawala Elecorindo.

Hasil penelitian ini sejalan dengan teori buku Sangadji dan Sopiah (2013:323), yang menyatakan bahwa "Merek merupakan suatu nama atau simbol yang mengidentifikasi suatu produk dan membedakannya dengan produkproduk lain sehingga mudah dikenali oleh konsumen ketika hendak membeli suatu produk. Keberadaan merek sangatlah penting bagi sebuah produk atau jasa, bahkan tidak mengherankan jika merek sering kali dijadikan kriteria untuk mengevaluasi suatu produk."

Hasil penelitian ini juga sesuai dengan penelitian Yudhi Soewito (2013) yang melakukan penelitian tentang Pengaruh Kualitas Produk, Merek Dan Desain Terhadap Keputusan Pembelian Sepeda Motor Yamaha Mio dengan hasil variabel kualitas produk, variabel merek dan variabel desain secara simultan dan parsial berpengaruh signifikan terhadap keputusan pembelian sepeda motor Yamaha Mio pada konsumen pengguna sepeda motor Yamaha Mio di kecamatan Singkil Manado. Peneliti terdahulu ini juga sejalan dengan hasil penelitian yang diteliti oleh peneliti dimana merek berpengaruh terhadap keputusan pembelian pada PT. Cakrawala Elecorindo.

Permasalahan merek yang ada di PT. Cakrawala Elecorindo adalah merek kurang dikenal oleh kalangan masyarakat sehingga konsumen menggunakan produk dari perusahaan lain yang sudah dikenal dikalangan masyarakat yang mengakibatkan menurunnya pembelian akan produk DVD player Elecor.

Hasil jawaban responden mengenai kuesioner merek, diketahui bahwa merek dvd player Elecor mudah dibaca dan diucapkan, kurang ingat dengan merek dvd yang ditawarkan oleh PT. Cakrawala Elecorindo, merek dvd player pada PT. Cakrawala Elecorindo singkat, merek dvd pada PT. Cakrawala Elecorindo sederhana, dvd pada PT. Cakrawala Elecorindo mempunyai ciri khas tersendiri, dvd player Elecor disenangi oleh konsumen, setuju bahwa dvd player Elecor menggambarkan kualitas, prestise, produk dan sebagainya, dvd player Elecor menggambarkan kualitas yang baik, setuju agar merek pada PT. Cakrawala Elecorindo melakukan pendaftaran merek, setuju sekali merek dengan perlindungan hukum akan dipilih oleh pelanggan. Dari hasil jawaban responden diatas dapat dilihat pada butir pertanyaan ingatkah anda dengan merek dvd yang ditawarkan oleh PT. Cakrawala Elecorindo pada Tabel IV.4 tentang penjelasan responden atas variabel merek dimana responden banyak yang menjawab kurang ingat terhadap merek dvd yang ditawarkan oleh PT. Cakrawala Elecorindo yaitu sebesar 52,9\%. Kesimpulan jawaban mengenai merek yaitu pengenalan merek kepada masyarakat perlu lebih ditingkatkan karena dengan merek yang terkenal akan dipilih oleh masyarakat.

\section{Pengaruh Personal Selling terhadap Keputusan Pembelian}

Hasil penelitian yang dilakukan peneliti membuktikan bahwa adanya pengaruh personal selling terhadap keputusan pembelian. Hal tersebut dibuktikan dengan hasil analisis uji $\mathrm{t}$ yaitu nilai $t_{\text {hitung }}>t_{\text {tabel }}(2,252>1.996)$ dan pada tingkat signifikan $(0,028<0,05)$. Hasil penelitian menunjukkan bahwa $\mathrm{H}_{1}$ diterima dan $\mathrm{H}_{0}$ ditolak. Hal ini menunjukkan bahwa personal selling secara parsial berpengaruh positif dan signifikan terhadap keputusan pembelian produk dvd player Elecor pada PT. Cakrawala Elecorindo.

Hasil penelitian ini sejalan dengan teori buku Hermawan (2012:108), yang menyatakan bahwa "Penjualan personal adalah komunikasi langsung (tatap muka) antara penjual dan calon pelanggan untuk memperkenalkan suatu produk kepada calon pelanggan dan membentuk pemahaman pelanggan terhadap produk sehingga mereka kemudian akan mencoba dan membelinya."

Hasil penelitian ini juga sesuai dengan penelitian yang dilakukan oleh Muslichah Erma Widiana dan Endah Rusmawati (2014), yang melakukan penelitian tentang Pengaruh Ekuitas Merek, Kualitas Produk dan Penjualan Perorangan Terhadap Keputusan Pembelian Produk Maspion di Desa Seruni Gedangan Sidoarjo dengan hasil variabel ekuitas merek, variabel kualitas produk, dan variabel penjualan perorangan secara simultan dan parsial berpengaruh terhadap keputusan pembelian produk Maspion di Desa Seruni, Gedangan Sidoarjo. Peneliti terdahulu ini juga sejalan 
dengan hasil penelitian yang diteliti oleh peneliti dimana personal selling berpengaruh terhadap keputusan pembelian pada PT. Cakrawala Elecorindo.

Permasalahan personal selling pada PT. Cakrawala Elecorindo adalah personal selling tidak memahami produk yang akan dijual dan tidak datang tepat waktu ke tempat pelanggan yang mengakibatkan penurunan penjualan pada PT. Cakrawala Elecorindo.

Hasil jawaban responden mengenai kuesioner mengenai personal selling terbukti bahwa personal selling berpengaruh terhadap keputusan pembelian. Hal ini diketahui dari jawaban responden yang menyatakan jika tenaga penjual PT. Cakrawala Elecorindo kurang mengerti tentang produk yang dijual, tenga penjual pada PT. Cakrawala Elecorindo sudang melakukan pendekatan dengan pelanggan, tenaga penjual PT. Cakrawala Elecorindo mampu bernegosiasi dengan pelanggan, tenaga penjual mampu sekali dalam memasarkan produk kepada pelanggan, hubungan tenaga penjual PT. Cakrawala Elecorindo dengan pelanggan baik, tenaga penjual PT. Cakrawala Elecorindo sudah mengenali karakter individu dari pelanggan. Dari hasil jawaban responden diatas dapat dilihat pada butir pertanyaan apakah tenaga penjual memiliki pengetahuan tentang produk yang dijual pada Tabel IV.4 tentang penjelasan responden atas variabel personal selling dimana responden banyak yang menjawab tenaga penjual pada PT. Cakrawala Elecorindo kurang mengerti produk yang dijual yaitu sebesar $60 \%$. Dari jawaban responden dapat disimpulkan personal selling berpengaruh terhadap keputusan pembelian, untuk itu perusahaan perlu fokus pada tenaga penjual, agar produk yang dijual dapat diketahui konsumen dengan jelas dan benar, selain itu perusahaan perlu mengadakan pelatihan bagi tenaga personal selling, agar mampu menjelaskan produk secara jelas.

\section{KESIMPULAN DAN SARAN Kesimpulan}

Berdasarkan hasil penelitian dan pembahasan yang telah diuraikan pada bab sebelumnya, maka dapat ditarik kesimpulan sebagai berikut:

1. Secara parsial terbukti variabel merek berpengaruh positif dan signifikan terhadap keputusan pembelian pada pada PT. Cakrawala Elecorindo, terbukti dari hasil perhitungan diperoleh $\mathrm{t}_{\text {hitung }}$ merek 5,518 sedangkan nilai $t_{\text {tabel }}$ yang diperoleh sebesar $1.996\left(\mathrm{t}_{\text {hitung }}>\mathrm{t}_{\text {tabel }}\right)$ dan tingkat signifikan pada level $0,000<0,05$.
NIAGAWAN Vol 7 No 2 Juli 2018

2. Secara parsial terbukti variabel personal selling berpengaruh positif dan signifikan terhadap keputusan pembelian pada PT. Cakrawala Elecorindo, terbukti dari hasil perhitungan diperoleh $t_{\text {hitung }}$ personal selling 2,252 sedangkan nilai $t_{\text {tabel }}$ yang diperoleh sebesar $1.996 \quad\left(t_{\text {hitung }}>t_{\text {tabel }}\right)$ dan tingkat signifikan pada level $0,028<0,05$.

3. Secara simultan merek dan personal selling berpengaruh positif dan signifikan terhadap keputusan pembelian pada PT. Cakrawala Elecorindo, terbukti dari hasil perhitungan diperoleh hasil uji $F_{\text {hitung }}(22,497)$ lebih besar dibandingkan dengan $F_{\text {tabel }}(3,13)$ dengan taraf signifikan lebih kecil dari 0,05.

Saran

Berdasarkan kesimpulan sebelummya, maka peneliti menyarankan perusahaan PT. Cakrawala Elecorindo Medan harus dapat menciptakan produk yang lebih unggul dibandingkan dengan produk merek lain, menghasilkan dvd player yang memiliki tampilan yang bagus agar dapat menarik para konsumen serta mengenalkan merek Elecor kepada masyarakat.. Selain itu, perusahaan memberikan pelatihan atau (trainning) tambahan kepada sumber daya manusia untuk lebih memahami akan pekerjaan yang sedang dijalaninya seperti personal selling lebih mampu menjelaskan spesifikasi-spesifiksi dan kelebihan yang terkandung dalam produk yang akan dijual. Dengan tujuan agar PT. Cakrawala Elecorindo dikenal sebagai perusahaan yang memiliki sumber daya manusia yang berkualitas dan berkemampuan.

\section{REFERENSI}

Arikunto, Suharsimi. 2010. Prosedur Penelitian Suatu Pendekatan Praktik. Jakarta: Rineka Cipta.

Feriyanto, Andri \& Endang Shyta Triana. 2015. Pengantar Manajemen (3 in 1). Tamanwinanngun : MEDIATERA.

Ghozali, Imam. 2011. Aplikasi Analisis Multivariate Dengan Program IBM SPSS 19. Semarang : Undip. .2013 . Aplikasi Analisis Multivariate Dengan Program. Ed.7, Semarang: Badan Penerbit Universitas Diponogoro.

Hasan, Ali. 2014. Marketing dan Kasus-Kasus Pilihan. Yogyakarta: CAPS (Center for Academic Publishing Service).

Hermawan, Agus. 2012. Komunikasi Pemasaran. Jakarta: Penerbit Erlangga.

Kotler, Philip \& Gary Armstrong. 2008. Prinsip-prinsip Pemasaran. Ed.12 Jilid 1, Jakarta: Penerbit Erlangga. 
Kotler, Philip \& Kevin Lane Keller. 2009.

Manejemen Pemasaran. Ed.13 Jilid 1, Jakarta: Penerbit Erlangga.

Laksana, Fajar. 2008. Manajemen Pemasaran, Pendekatan Praktis. Yogyakarta : Graha Ilmu.

Priyatno, Duwi. 2012. Cara Kilat Belajar Analisis Data dengan SPSS 20. Yogyakarta: Andi Offset.

Rachman, Taufiq. 2010. Manajemen Pemasaran. Medan: Perdana Publishing.

Rangkuti, Freddy. 2009. Strategi Promosi yang Kreatif \& Analisis Kasus Integrated Marketing Communication. Jakarta: PT. Gramedia Pustaka Utama.

Sangadji, Mamang Etta \& Sophiah. 2013. Perilaku Konsumen Pendekatan Praktis. Yogyakarta: Andi Offset.

Sanusi, Anwar. 2011, Metode Penelitian Bisnis. Jakarta : Salemba Empat. . 2014. Metodologi Penelitian Bisnis. Jakarta : Salemba Empat.

Sugiyono. 2008. Metode Penelitian Kuatintatif, Kualitatif dan R\&D. Bandung: Penerbit Alfabeta.

2012. Metode Penelitian Kuantitatif Kualitatif dan R\&D. Bandung : Penerbit Alfabeta. . 2013. Metode Penelitian Bisnis.

Bandung: Penerbit Alfabeta.

2015. Metode Penelitian Manajemen. Bandung: Penerbit Alfabeta.

Sujarweni, Wiratna. 2015. Metode Penelitian Bisnis \& Ekonomi. Yogyakarta: Penerbit Pustaka Baru Press.

Sunyoto, Danang. 2012. Konsep Dasar Riset Pemasaran \& Perilaku Konsumen. Yogyakarta: CAPS (Center for Academic Publishing Service).

2013. Perilaku Konsumen (Panduan Riset Sederhana untuk Mengenali Konsumen). Yogyakarta: CAPS (Center for Academic Publishing Service).

2014. Dasar-dasar

Manajemen Pemasaran (Konsep, Strategi, dan Kasus). Yogyakarta: CAPS (Center for Academic Publishing Service).

. 2014. Praktik Riset Perilaku Konsumen (Kuesioner, Alat, dan Analisis Data). Yogyakarta: CAPS (Center for Academic Publishing Service).

Swastha, Basu. 2012. Manajemen Penjualan. Ed.3, Yogyakarta : BPFE - Yogyakarta.

Tjiptono, Fandy \& Gregorius Chandra. 2012. Pemasaran Strategik. Ed. II, Yogyakarta: Andi Offset.

Zulganef. 2013. Metode Penelitian Sosial \& Bisnis. Ed.1, Yogyakarta: Graha Ilmu. 